\title{
Pengujian Kuat-Lentur Bambu Petung Yang Diawetkan Dengan Metode Perebusan
}

\author{
Efa Suriani \\ Universitas Islam Negeri Sunan Ampel, Surabaya, Indonesia \\ efasuriani@gmail.com \\ doi.org/10.29080/eija.v4i2.418
}

\begin{abstract}
The use of bamboo material has been known for its use since ancient times. But bamboo is also known to have several disadvantages, including being vulnerable to termites and fungi attacks when exposed to water. Therefore special treatment is needed to prolong the use of bamboo if it is to be used as construction material. The boiling preservation method become one of the recent methods applied to meet long-lasting bamboo supply, in addition to the Visual Soak Diffusion (VSD) method which tends to take longer time. The purpose of this study was to determine the mechanical properties of the flexural strength of Petung bamboo with boiling preservation method. The test results showed a significant increase in bamboo flexural strength (twenty percent stronger), after being preserved by the boiling method, although the water content in bamboo increased which affected the potential for fungal attack. This can be overcome by adding anti-fungal material to the preservation solution. The boiling preservation method is able to become main alternative to substituting chemical preservatives.
\end{abstract}

Keywords: bamboo petung, bamboo preservation, flexural strength

Abstrak: Penggunaan material bambu telah dikenal penggunaannya sejak jaman dahulu. Namun bambu juga dikenal memiliki beberapa kelemahan, diantaranya rentan terhadap serangan rayap dan jamur bila terkena air. Oleh karenanya diperlukan perlakuan khusus untuk memperpanjang usia penggunaan bambu bila hendak digunakan sebagai material konstruksi. Metode pengawetan dengan perebusan adalah salah satu metode baru yang diterapkan dilapangan untuk memenuhi pasokan bambu awet, selain metode Visual Soak Diffusion (VSD) yang cenderung memakan waktu yang lebih lama. Tujuan penelitian ini adalah untuk mengetahui sifat mekanik kuat-lentur bambu Petung dengan metode pengawetan perebusan. Hasil pengujian memperlihatkan peningkatan kuat-lentur bambu yang signifikan (dua puluh persen lebih kuat-lentur) setelah diawetkan dengan metode perebusan, meskipun kadar air dalam bambu meningkat yang berimbas pada potensi serangan jamur. Hal ini dapat diatasi dengan cara menambahkan bahan anti jamur pada larutan pengawetan. Metode pengawetan dengan perebusan ini mampu menjadi alternatif utama pengganti bahan pengawet kimia.

Kata Kunci: bambu petung, pengawetan bambu, kuat-lentur

\section{PENDAHULUAN}

Material bambu merupakan material dari alam yang masing-masing memiliki karakteristik dan keunggulan tersendiri. Material bambu sudah dikenal sejak dulu dan menjadi bagian dari budaya nenek moyang terdahulu. Namun, seiring dengan perkembangan teknologi material, posisi bambu tergeser oleh material modern seperti beton bertulang, precast dan material baja. Selain itu, terbatasnya pengetahuan tentang teknologi pengolahan bambu pada akhirnya menambah berkurangnya peminatan penggunaan bambu di masyarakat.

Di lain sisi isu pemanasan global selama satu dekade terakhir menuntut bangunan untuk menerapkan konsep green building, yang berimbas kepada pemanfaatan material bahan bangunan yang ramah lingkungan (Suriani, 2017). Salah satu kriteria ramah lingkungan adalah pemanfaatan material ekologis, dimana bambu termasuk didalamnya dan menjadi alternatif solusi. Hal ini dikarenakan sifat material bambu yang cepat tumbuh dan dipanen, menjadikannya sebagai sumber daya yang berkelanjutan dan lestari. Bambu juga memiliki kekuatan yang tinggi dan mudah ditemukan di sekitar lingkungan manusia (Morisco, 1999). Akan tetapi bambu dengan berbagai manfaatnya tidak dapat digunakan dengan baik bila keberadaanya sudah mulai hilang atau punah (Widnyana, 2008)

Indonesia sendiri memiliki 120 jenis bambu dan 65 jenis bambu merupakan tanaman asli dari wilayah Indonesia (Widjaja, 2000). Akan tetapi keraguan mayarakat Indonesia untuk menggunakan bambu sebagai bahan bangunan masih tinggi. Padahal bambu diyakini dapat menjadi material yang 
berkelanjutan untuk memenuhi pasokan material perumahan (Mustakim et al, 2009). Hal ini dikarenakan masa layan atau umur konstruksi bambu relatif singkat dibandingkan dengan menggunakan beton atau baja. Pendeknya masa umur konstruksi bambu umumnya dikarenakan serangan rayap dan jamur, terlebih bila bersentuhan langsung dengan air atau udara lembab.

Untuk mengatasi kelemahan tersebut diperlukan perlakuan khusus sebelum menggunakan material bambu baik untuk bahan interior atau bahan konstruksi bangunan. Perlakuan khusus yang dimaksud berupa pengawetan terhadap bambu sebelum digunakan. Metode pengawetan yang umumnya dilakukan dilapangan biasanya menggunakan metode pengawetan Vertical Soak Diffusion (VSD), yaitu metode pengawetan dengan cara memasukkan bahan pengawet dengan posisi bambu didirikan. Dengan demikian bahan pengawet menyebar dengan cara difusi dari atas ke bawah memanfaatkan gaya gravitasi. Namun pengawetan dengan metode ini memerlukan waktu yang cukup lama, sehingga, diperlukan metode pengawetan yang dapat digunakan dengan waktu yang relatif singkat untuk memenuhi pesanan bambu awet sesuai permintaan pasar. Pada penelitian sebelumnya, metode pengawetan dengan bahan kimia borax-boric konsentrasi $10 \%$ juga mampu menambah usia layan bambu, tapi metode ini cenderung kurang ramah terhadap lingkungan. (Suriani, 2018)

Alternatif metode pengawetan bambu yang juga lazim ditemui adalah dengan metode perebusan, akan tetapi sifat fisis-mekanik dengan metode pengawetan dengan cara perebusan belumlah dapat diketahui dengan pasti. Padahal sangat penting untuk mengetahui sifat fisis dan mekanik bambu memperoleh informasi karakteristik material yang dapat digunakan sebagai dasar pertimbangan dalam perancangan konstruksi bambu. Sifat fisis adalah sifat yang dimilki oleh bahan tanpa memerlukan usaha atau perlakuan yang dapat merubah benda tersebut. Dalam penelitian ini sifat fisis yang diamati adalah kadar air dan kerapatan. Kadar air sendiri merupakan indikator banyaknya kandungan air yang ada didalam sepotong bambu yang dirumuskan dalam persentase dari berat kering tanurnya. Sedangkan kerapatan merupakan perbandingan massa suatu benda dengan volumenya. Kerapatan diformulasikan sebagai perbandingan antara massa kering tanur suatu benda terhadap massa suatu volume air yang sama dengan volume benda tersebut. Uji kadar air diambil pada pangkal bagian bambu bahan uji

Sedangkan untuk sifat mekanik direpresentasikan oleh kuat lentur, yang didefinisikan sebagai kemampuan dalam menerima beban yang bekerja tegak lurus sumbu memanjang serat di tengah-tengah bahan yang ditumpu keduanya (Pathurahman, 1998).
Sedangkan menurut Sumarni (2010) sifat mekanik merupakan suatu usaha untuk dapat mengukur suatu bahan dalam menahan gaya-gaya dari luar yang mengenainya. Penelitan ini bertujuan mengetahui sifat mekanik kuat-lentur bambu, dalam hal ini Bambu Petung, dengan metode pengawetan perebusan. Data ini menjadi penting untuk mengetahui karakteristik bambu yang diawetkan dengan perebusan yang dapat digunakan sebagai dasar dalam perancangan konstruksi bambu.

\section{METODE PENELITIAN}

Metode penelitian yang digunakan adalah metode eksperimental laboratorium. Eksperimen pengujian yang dilakukan untuk mengetahui kuat lentur bambu Petung dengan metode empat titik uji lentur. Metode pengujian ini berdasarkan ISO 22157-1 tentang "Bamboo-Determination of physical and mechanical properties dan ISO 22157-2 tentang Bamboo-Determination of physical and mechanical properties Sebelum proses pengujian dilangsungkan, terlebih dahulu dipersiapkan benda uji yang berupa bambu yang sudah diawetkan dengan metode perebusan. Masing-masing bambu petung yang diawetkan dengan perebusan dan yang tanpa pengawetan akan diuji ulang masing-masing sebanyak tiga kali. Pengujian dilakukan terhadap dua sifat bambu, yakni sifat mekanika berupa kuat-lentur bambu, serta sifat fisis bambu yang meliputi kadar air dan kerapatan pada bambu yang diuji.. Proses perebusan bahan uji dilakukan selama sekitar tiga jam dengan suhu mencapai 80 s.d $100{ }^{\circ} \mathrm{C}$ didalam campuran air bersih dan bahan pengawet berupa borax-boric kadar $10 \%$. Setelah selesai direbus bahan uji diangkat dan ditiriskan untuk kemudian dikeringkan dengan cara diangin-anginkan (gambar 1).

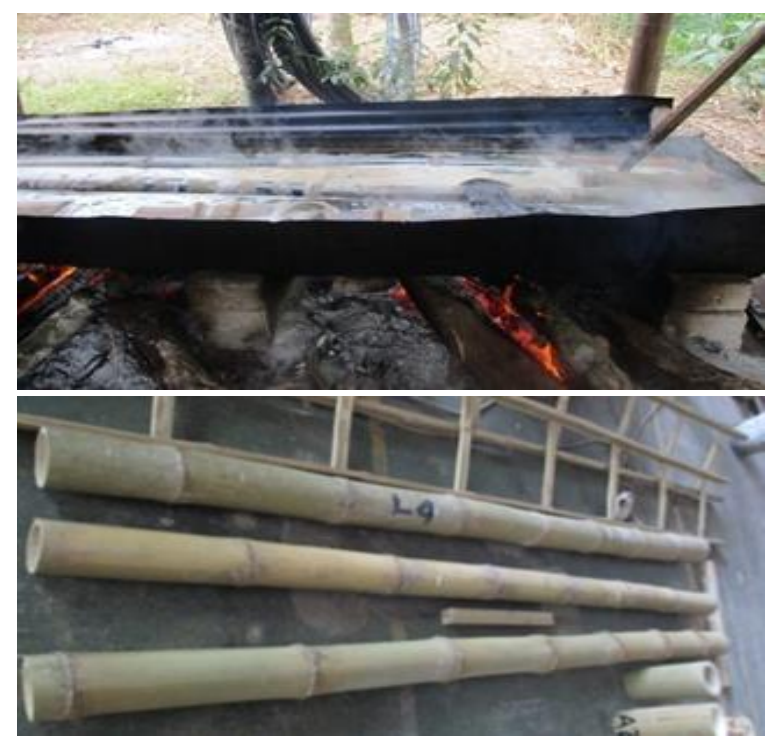

Gambar 1. Proses perebusan bahan uji dalam drum pengawet (atas) dan materil bahan siap uji (bawah) (sumber: dokumentasi peneliti, 2018) 
Setelah bahan uji siap, maka tahap selanjutnya adalah melakukan setting alat pengujian bambu (gambar 2). Pengujian ini dilakukan dengan menggunakan Data Logger dan Load Cell kapasitas $100 \mathrm{KN}$ dan untuk mengukur perubahan panjang menggunakan dua buah Linear Variable Differential Transformer (LVDT). Prosedur pemberian pembebanan untuk pengujian untuk uji kuat-lentur menggunakan tenaga manusia pada hydraulic jack. Pemberian pembebanan dilakukan secara manual sampai terjadi kerusakan pada benda uji.
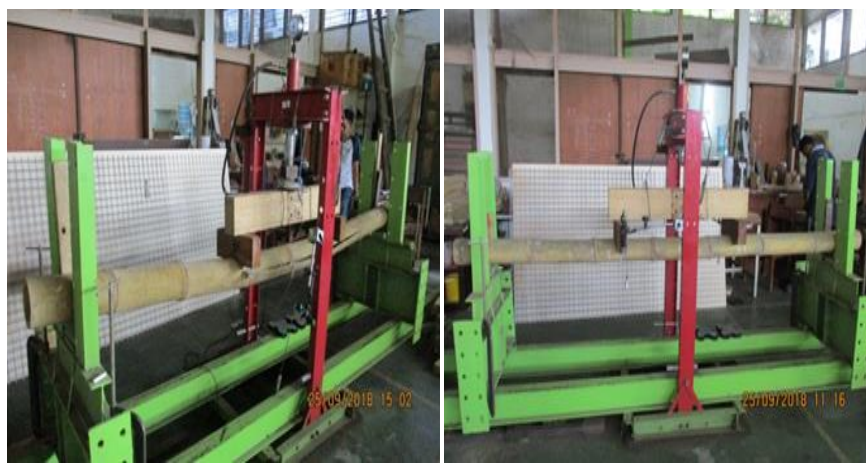

Gambar 2. Setting alat uji dan pengujian kuat-lentur bambu (sumber: dokumentasi 2018)

\section{HASIL DAN PEMBAHASAN}

\subsection{Perilaku dan Kerusakan benda Uji}

Pengujian kuat lentur bambu Petung yaitu untuk kasus bambu bulat atau utuh biasanya digunakan pemberian satu pembebanan pada bentang atau tiga titik uji lentur. Namun, penelitian ini menggunakan pemberian dua pembebanan pada bentang atau dengan metode 4 titik uji lentur. Perbedaan area momen lentur murni dapat dilihat pada gambar 3 .

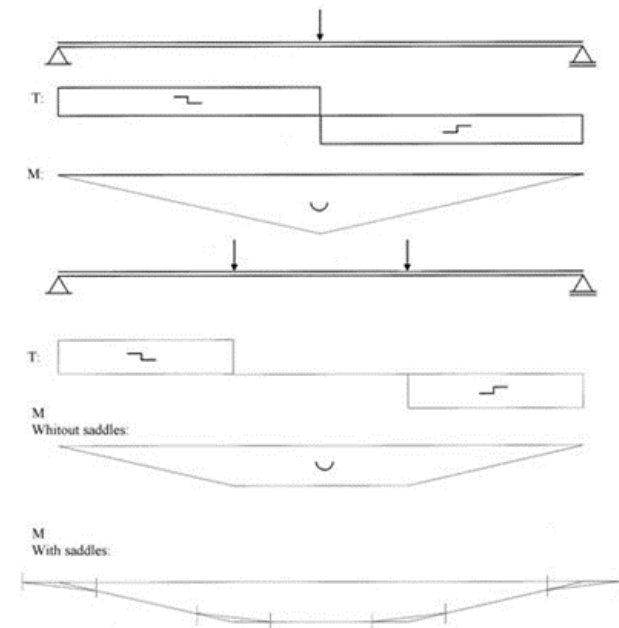

Gambar 3. Diagram momen dan gaya geser 3 titik dan 4 titik uji lentur (Sumber: ISO/TR 22157-2, 2004)

Posisi dan jarak perletakan pembebanan pada benda uji pengujian kuat lentur bambu Petung juga perlu diperhatikan. Posisi tersebut akan mempengaruhi perilaku hasil pengujian. Benda uji diletakkan pada setting alat pada tumpuan sendi dan roll. Bagian pangkal bambu diletakkan pada bagian tumpuan roll, seperti pada gambar 4 .

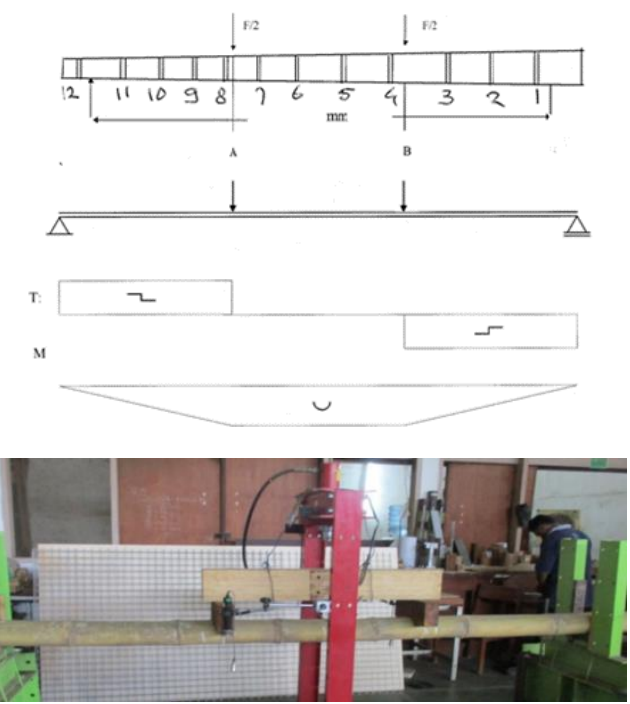

Gambar 4. Posisi dan letak benda uji. (Sumber: analisis dan dokumentasi peneliti, 2018).

Perilaku tersebut terjadi pada benda uji bambu Petung tanpa pengawetan dan dengan pengawetan metode perebusan. Hal ini memperlihatkan bahwa bagian yang mampu menahan pembebanan adalah bagian pangkal, sedangkan bagian lemah adalah bagian antara tengah menuju ujung bambu Petung. Jenis atau model kerusakan pada pengujian dapat dilihat pada gambar dibawah ini. Kerusakan yang terjadi bambu pecah atau bagian yang rusak atau remuk saddle atau dudukan pembebanan masuk kedalam bagian bambu (gambar 5).

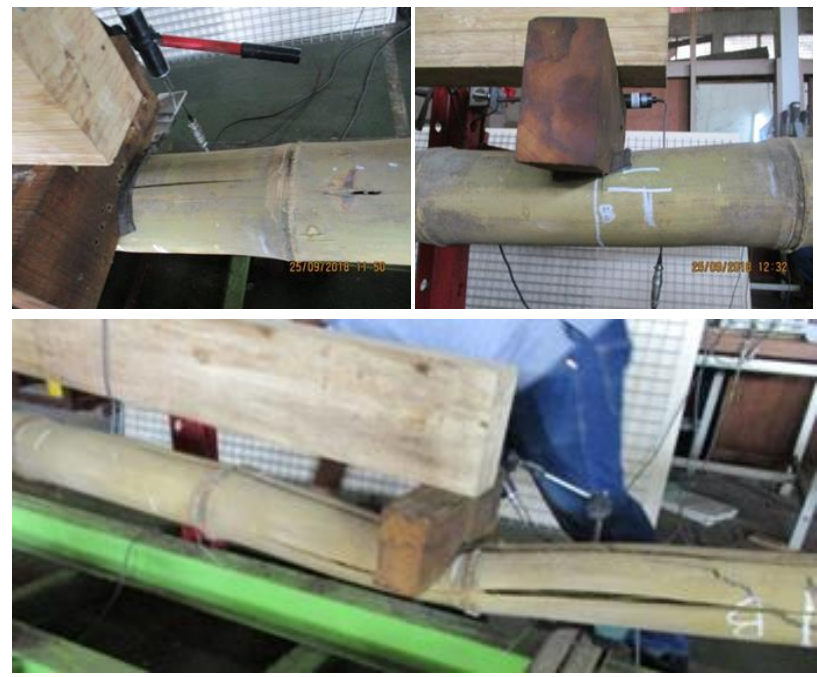

Gambar 5. Bagian bambu remuk dengan arah kerusakan mengarah ke bagian dalam bambu (atas) dan bagian kerusakan pecah antara bagian tengah menuju ujung bambu (bawah) (sumber: dokumentasi peneliti, 2018) 
Selain itu, yang perlu diperhatikan adalah kondisi fisik yang dapat dilihat pada bahan uji bambu Petung setelah selesai proses perebusan. Jeda waktu antara pengeringan bambu dengan pengujian menunjukkan kemunculan bercak-bercak jamur di sepanjang bagian bambu (gambar 6). Hal ini mengindikasikan bahwa proses pengawetan dengan metode perebusan masihlah rawan terhadap jamur, sehingga perlu ditambahkan bahan anti jamur selain bahan pengawet borak dan boric.

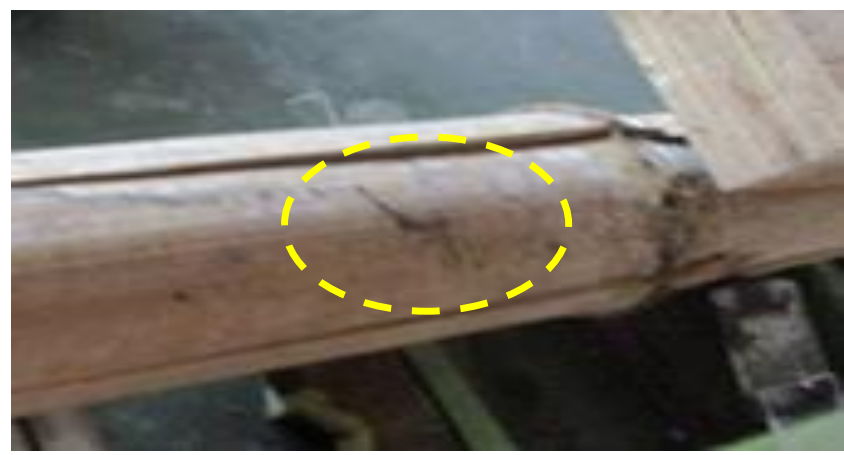

Gambar 6. Bercak jamur pada bagian bahan uji bambu (sumber: dokumentasi peneliti, 2018)

\subsection{Sifat fisis bahan uji}

. Hasil perhitungannya untuk bahan uji 1 dan 2 yang tanpa perlakuan pengawetan terlihat pada tabel 1 dan 2. Label TP berarti Tanpa Pengawetan dan label $P$ untuk pengawetan.

Tabel 1. Kadar air tanpa pengawetan pada bahan uji 1

\begin{tabular}{ccc}
\hline No. & Label & Kadar air $(\%)$ \\
\hline 1 & TP11 & 17,0103 \\
2 & TP12 & 18,3767 \\
3 & TP13 & 17,0418 \\
4 & TP14 & 16,9406 \\
5 & TP15 & 17,8515 \\
6 & TP16 & 17,5159 \\
7 & TP17 & 17,4579 \\
8 & TP18 & 18,0912 \\
9 & TP19 & 18,2081 \\
10 & TP110 & 18,0758 \\
\hline \multicolumn{2}{c}{ Rata-rata }
\end{tabular}

Sumber: hasil analisis (2018)

Tabel 2. Kadar air tanpa pengawetan pada bahan uji 2

\begin{tabular}{ccc}
\hline No. & Label & Kadar air (\%) \\
\hline 1 & TP21 & 14,0430 \\
2 & TP22 & 13,7132 \\
3 & TP23 & 13,4009 \\
4 & TP24 & 14,5608 \\
5 & TP25 & 13,1268
\end{tabular}

\begin{tabular}{ccc}
\hline 6 & TP26 & 13,8705 \\
7 & TP27 & 14,1732 \\
8 & TP28 & 14,1921 \\
9 & TP29 & 13,9744 \\
10 & TP210 & 13,7584 \\
\hline \multicolumn{2}{c}{ Rata-rata } & $\mathbf{1 3 , 8 8 1 3}$ \\
\hline
\end{tabular}

Sumber: hasil analisis (2018)

Hasil menunjukkan rata-rata kadar air untuk bahan uji tanpa pengawetan dapat mencapai kisaran $13.8813 \%$ sampai dengan $17.6570 \%$. Hasil pengukuran ini masih dalam batas rentang dengan penelitian Oka (2005) yang menyatakan rata-rata kadar air pada bambu petung mencapai $12.63 \%$, dan $15.38 \%$ pada penelitian yang dilakukan oleh Irawati dan Saputra (2012). Hasil pengujian kadar air untuk bahan uji 1 dan 2 yang mendapat perlakuan pengawetan dapat dilihat pada tabel 3 dan 4 berikut ini.

Tabel 3. Kadar air pada bahan uji 1 dengan pengawetan

\begin{tabular}{ccc}
\hline No. & Label & Kadar air (\%) \\
\hline 1 & $\mathrm{P} 11$ & 34,0295 \\
2 & $\mathrm{P} 12$ & 44,0645 \\
3 & $\mathrm{P} 13$ & 42,7599 \\
4 & $\mathrm{P} 14$ & 34,7387 \\
5 & $\mathrm{P} 15$ & 37,2136 \\
6 & $\mathrm{P} 16$ & 35,1081 \\
7 & $\mathrm{P} 17$ & 37,8864 \\
8 & $\mathrm{P} 18$ & 41,2797 \\
9 & $\mathrm{P} 19$ & 31,2362 \\
10 & $\mathrm{P} 110$ & 38,5177 \\
\hline \multicolumn{3}{c}{ Rata-rata } \\
\hline
\end{tabular}

Sumber: hasil analisis (2018)

Tabel 4. Kadar air pada bahan uji 2 dengan pengawetan

\begin{tabular}{ccc}
\hline No. & Label & Kadar air (\%) \\
\hline 1 & P21 & 27,7427 \\
2 & P22 & 24,8241 \\
3 & P23 & 24,3324 \\
4 & P24 & 22,4788 \\
5 & P25 & 23,7412 \\
6 & P26 & 28,4649 \\
7 & P27 & 26,6161 \\
8 & P28 & 28,2947 \\
9 & P29 & 26,0039 \\
10 & P210 & 24,7847 \\
\hline \multicolumn{3}{c}{ Rata-rata }
\end{tabular}

Sumber: hasil analisis (2018) 
Dari tabel 3 dan 4 terlihat bahwa rata-rata kadar air untuk bahan uji yang mendapat perlakuan pengawetan mencapai kisaran $25.7283 \%$ sampai dengan $37.6834 \%$. Hasil pengukuran kadar air pada bahan uji menunjukkan kadar air pada bambu yang diawetkan dengan metode perebusan meningkat dua kali lipat $(100 \%)$ bila dibandingkan pada bambu yang tanpa melalui pengawetan dengan metode perebusan Kemudian untuk hasil pengukuran kerapatan bahan uji untuk bahan uji 1 dan 2 yang tanpa perlakuan pengawetan dapat dilihat pada tabel 5 dan 6 berikut ini

Tabel 5. Kerapatan pada bahan uji 1 tanpa pengawetan

\begin{tabular}{ccc}
\hline No. & Label & Kerapatan $\left(\mathbf{g} / \mathbf{c m}^{3}\right)$ \\
\hline 1 & TP11 & 0,4613 \\
2 & TP12 & 0,4645 \\
3 & TP13 & 0,4251 \\
4 & TP14 & 0,4329 \\
5 & TP15 & 0,3906 \\
6 & TP16 & 0,4275 \\
7 & TP17 & 0,4236 \\
8 & TP18 & 0,4323 \\
9 & TP19 & 0,4258 \\
10 & TP110 & 0,4892 \\
\hline \multicolumn{2}{c}{ Rata-rata } \\
\hline
\end{tabular}

Sumber: hasil analisis (2018)

Tabel 6. Kerapatan pada bahan uji 2 tanpa pengawetan

\begin{tabular}{ccc}
\hline No. & Label & Kerapatan $\left(\mathbf{g} / \mathbf{c m}^{3}\right)$ \\
\hline 1 & TP21 & 0.5631 \\
2 & TP22 & 0.5467 \\
3 & TP23 & 0.5012 \\
4 & TP24 & 0.4464 \\
5 & TP25 & 0.4359 \\
6 & TP26 & 0.4835 \\
7 & TP27 & 0.5191 \\
8 & TP28 & 0.5834 \\
9 & TP29 & 0.4761 \\
10 & TP210
\end{tabular}

Sumber: hasil analisis (2018)

Dari tabel 5 dan 6 terlihat bahwa rata-rata kerapatan untuk bahan uji yang tanpa pengawetan mencapai kisaran $0.4373-0.5127 \mathrm{gr} / \mathrm{cm} 3$. Sedangkan untuk rata-rata kerapatan bahan uji untuk bahan uji 1 dan 2 yang mendapat perlakuan pengawetan dengan perebusan berada pada kisaran 0.4306 - 0.5586 $\mathrm{gr} / \mathrm{cm} 3$. (lihat tabel 7 \& 8 untuk detail hasil pengukuran).
Tabel 7. Kerapatan pada bahan uji 1 dengan pengawetan

\begin{tabular}{|c|c|c|}
\hline No. & Label & Kerapatan $(\mathrm{g} / \mathrm{cm} 3)$ \\
\hline 1 & P11 & 0,4645 \\
\hline 2 & P12 & 0,3503 \\
\hline 3 & P13 & 0,3242 \\
\hline 4 & P14 & 0,5129 \\
\hline 5 & P15 & 0,5244 \\
\hline 6 & P16 & 0,3837 \\
\hline 7 & P17 & 0,3705 \\
\hline 8 & P18 & 0,4334 \\
\hline 9 & P19 & 0,5862 \\
\hline 10 & $\mathrm{P} 110$ & 0,3559 \\
\hline \multicolumn{2}{|c|}{ Rata-rata } & 0,4306 \\
\hline \multicolumn{3}{|c|}{ Sumber: hasil analisis (2018) } \\
\hline Tabel & $\begin{array}{l}\text { Kerapata } \\
\text { pengawe }\end{array}$ & bahan uji 2 \\
\hline No. & Label & Kerapatan $\left(\mathrm{g} / \mathrm{cm}^{3}\right)$ \\
\hline 1 & P21 & 0,5829 \\
\hline 2 & P22 & 0,4896 \\
\hline 3 & P23 & 0,6460 \\
\hline 4 & P24 & 0,5033 \\
\hline 5 & P25 & 0,5963 \\
\hline 6 & P26 & 0,6137 \\
\hline 7 & P27 & 0,5087 \\
\hline 8 & P28 & 0,5707 \\
\hline 9 & P29 & 0,5056 \\
\hline 10 & P210 & 0,5691 \\
\hline \multicolumn{2}{|c|}{ Rata-rata } & 0,5586 \\
\hline
\end{tabular}

Sumber: hasil analisis (2018)

Dengan demikian dapat diketahui bahwa kerapatan bambu petung yang mendapat perlakuan pengawetan perebusan meningkat sebesar $4,13 \%$ bila dibandingkan kerapatan bahan uji yang yang tidak mendapatkan pengawetan.

\subsection{Sifat mekanik bahan uji}

Hasil pengujian sifat mekanik pada bahan uji dijabarkan sebagai berikut:

Tabel 9. Pembebanan (KN) dan deformasi $(\mathrm{mm})$ untuk benda uji tanpa pengawetan

\begin{tabular}{cccc}
\hline No & Label & Beban(N) & Deformasi $(\mathbf{m m})$ \\
\hline 1 & TP1 & 20323,1 & 51,075 \\
2 & TP2 & 31422,2 & 100,4 \\
3 & TP3 & 26948,1 & 54,125 \\
\hline \multicolumn{2}{c}{ Rata-rata } & $\mathbf{2 6 2 3 1 , 1 3 3 3}$ & $\mathbf{6 8 , 5 3 3 3}$
\end{tabular}

Sumber: hasil analisis (2018) 


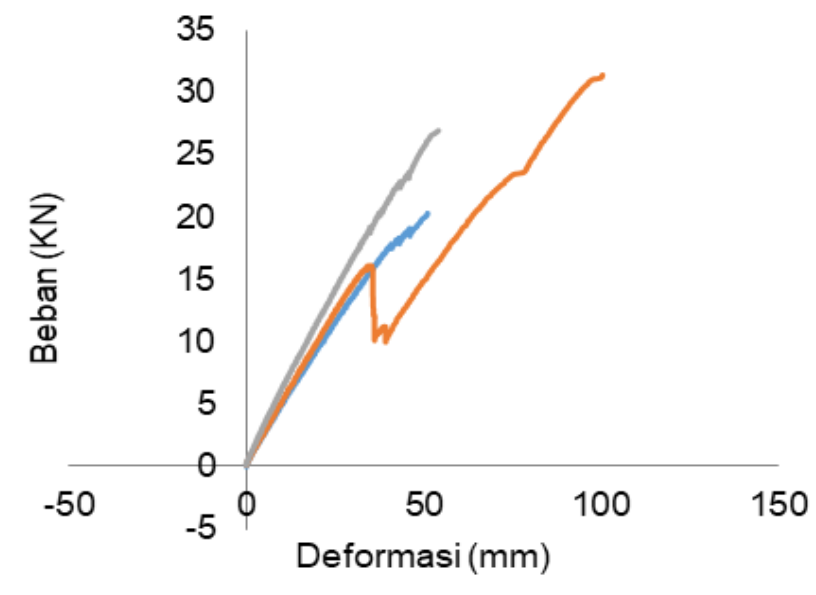

Gambar 7. Grafik pembebanan (KN) dan deformasi $(\mathrm{mm})$ untuk benda uji tanpa pengawetan (sumber: hasil analisis, 2018)

Pada tabel 9 dan gambar 7 memperlihatkan hasil pengujian kuat-lentur terhadap pembebanan dan deformasi dari bahan uji tanpa pengawetan memperlihatkan pola grafik yang cenderung fluktuatif. Hal ini diakibatkan karena pemberian pembebanan dengan tenaga manusia dan pencatatan kenaikan pembebanan dan deformasi tergantung alat yang digunakan. Hasil pembebanan dan deformasi untuk benda uji dengan pengawetan terlihat pada tabel 10 dan gambar 8 berikut.

Tabel 10. Pembebanan (KN) dan deformasi (mm) untuk benda uji dengan pengawetan perebusan

\begin{tabular}{cccc}
\hline No & Label & Beban(N) & Deformasi $(\mathbf{m m})$ \\
\hline 1 & $\mathrm{P} 1$ & 27198,1 & 54,7 \\
2 & $\mathrm{P} 2$ & 35823,1 & 59,125 \\
\hline \multicolumn{2}{c}{ Rata-rata } & $\mathbf{3 1 5 1 0 , 6}$ & $\mathbf{5 6 , 9 1 2 5}$ \\
\hline
\end{tabular}

Sumber: hasil analisis (2018)

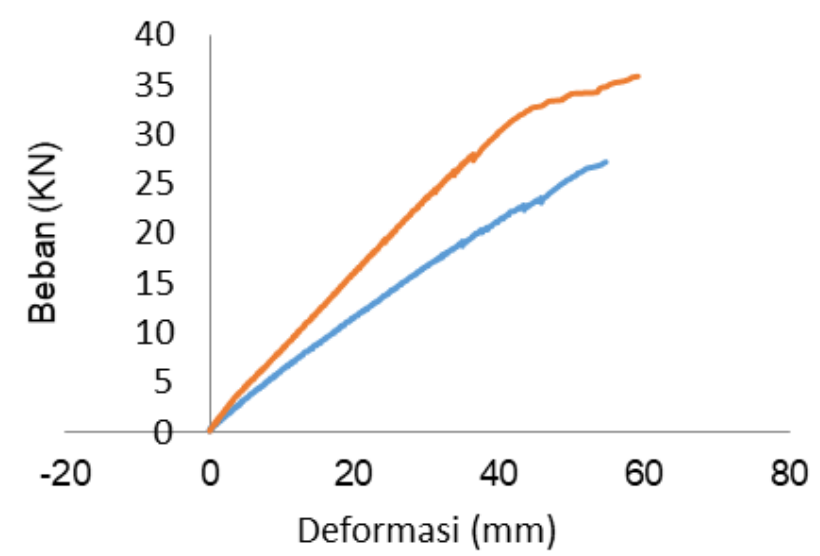

Gambar 8. Grafik pembebanan (KN) dan deformasi $(\mathrm{mm})$ untuk benda uji dengan pengawetan perebusan (sumber: hasil analisis, 2018)
Beban maksimum untuk benda uji tanpa pengawetan rata-rata adalah $26231.1333 \mathrm{~N}$, sedangkan beban maksimum untuk benda uji dengan pengawetan sebesar $31510.6 \mathrm{~N}$. Berdasarkan hasil tersebut dapat disimpulkan bahwa bambu Petung yang diawetkan dengan metode perebusan mampu menahan pembebanan sebesar $20.13 \%$ daripada bambu Petung yang tidak mendapatkan pengawetan.. Dari hasil pembebanan dan analisis deformasi tersebut dilakukan perhitungan untuk menentukan kuat-lentur bahan uji. Tabel 11 berikut menunjukkan perhitungan kuat lentur untuk benda uji tanpa pengawetan (TP) dan benda uji dengan pengawetan perebusan $(P)$.

Tabel 11. Hasil perhitungan kuat-lentur bahan uji tanpa dan dengan pengawetan perebusan

\begin{tabular}{cccc}
\hline No & Label & Beban(N) & $\begin{array}{c}\text { Kuat Lentur } \\
\left(\mathbf{N} / \mathbf{m m}^{\mathbf{2}}\right)\end{array}$ \\
\hline 1 & TP1 & 20323,1 & 51,11028623 \\
2 & TP2 & 31422,2 & 118,3387642 \\
3 & TP3 & 26948,1 & 108,0594011 \\
\hline \multicolumn{2}{r}{ Rata-rata tanpa pengawet } & $\mathbf{9 2 , 5 0 2 8 1 7 1 7}$ \\
\hline 1 & P1 & 27198,1 & 102,4304327 \\
2 & P2 & 35823,1 & 134,91294 \\
\hline \multicolumn{4}{r}{ Rata-rata dengan pengawetan }
\end{tabular}

Sumber: hasil analisis (2018)

Hasil pengujian kuat lentur dari bahan uji tanpa pengawetan kuat lentur rata-rata $92.5028 \mathrm{~N} / \mathrm{mm}^{2}$ dan benda uji dengan pengawetan kuat lentur rata-rata $118.6716 \mathrm{~N} / \mathrm{mm}^{2}$. Hasil pengujian kuat-lentur menunjukkan ada peningkatan kuat-lentur bambu Petung yang diawetkan dengan perebusan bila dibandingkan dengan bambu yang tanpa pengawetan dengan nilai peningkatan kuat lentur sebesar $22.05 \%$.

\section{KESIMPULAN}

. Dari hasil uji juga dapat diketahui bahwa bagian pangkal bambu yang diawetkan dengan metode perebusan dapat menahan beban lebih tinggi terhadap kerusakan dibandingkan bagian lain. Hasil uji menunjukkan terdapat peningkatan penerimaan beban maksimum dan kuat lentur sebesar 20\% setelah bambu diawetkan dengan metode perebusan, meskipun kadar air dalam bambu turut meningkat. Kelemahan metode ini terletak pada kerentanan terhadap serangan jamur, namun hal ini bisa dikondisikan dengan menambah bahan anti jamur pada bahan pengawet. Metode perebusan ini pun dapat menjadi alternatif pengawetan bambu untuk material konstruksi. Selanjutnya, perlu dilakukan penelitian lebih lanjut untuk memperoleh bahan pengawet yang lebih ramah lingkungan sebagai bahan pengganti pengawet kimia yang digunakan pada penelitian ini, sehingga diharapkan mampu menambah usia layan dari konstruksi bambu. 


\section{DAFTAR PUSTAKA}

Irawati, I., \& Saputra, A. (2012). Analisis statistik sifat mekanika bambu petung. Proceeding Simposium Sinar Bambu I. Yogyakarta.

ISO 22157-1. (2004). Bamboo -- Determination of physical and mechanical properties -- Part 1 : Requirements. Retrieved October 2, 2018, from

http://www.iso.org/cms/render/live/en/sites/iso org/contents/data/standard/03/61/36150.html

ISO 22157-2. (204AD). Bamboo -- Determination of physical and mechanical properties -- Part 2: Laboratory manual. Retrieved October 2, 2018, from http://www.iso.org/cms/render/live/en/sites/iso org/contents/data/standard/03/83/38360.html

Morisco, R. (1999). Rekayasa Bambu. Yogyakarta: Nafiri Offset.

Oka, G. M. (2005). Cara Penentuan Kelas Kuat Acuan Bambu Petung. MEKTEK, 7(2).

Sumarni, S. (2010). Struktur Kayu. Surakarta: Yuma Pustaka.
Suriani, E. (2017). Bambu Sebagai Alternatif Penerapan Material Ekologis: Potensi dan Tantangannya. EMARA Indonesian Journal of Architecture, 3(1), 33-42. doi:10.29080/emara.v3i1.138

Suriani, E. (2018). Kajian Terhadap Variasi Metode dan Bahan Pengawet pada Proses Pengawetan Bambu-Kayu di Indonesia. EMARA Indonesian Journal of Architecture, 4(1), 5464. doi:10.29080/emara.v4i1.338

Widjaja, E. (2000). Bamboo Diversity and Its Future Prospect in Indonesia (pp. 235-240). Presented at the Proceedings of The Third International Wood Science Symposium.

Widnyana, K. (2008). Bambu dengan Berbagai Manfaatnya. Bumi Lestari Journal of Environment, 8(1). Retrieved from https://ojs.unud.ac.id/index.php/blje/article/vie $w / 2418$ 